\title{
Current Situation and Development Strategy of Preschool Art Education
}

\author{
Shufang Xiao, Zhiyuan Xiao \\ (Guizhou Vocational College of Electronic and Information Technology) \\ Xiao Shufang (1985-), female, Buyi nationality. Kaili City, Guizhou Province, Guizhou Institute of Electronic and \\ Information Technology, Ph.D. University of Thailand, Gree University, Research Interest: Education Management. \\ E-mail: 568904689@qq.com \\ Abstract: In recent years, with the continuous deepening of education reform, the education sector has put forward \\ higher requirements for early childhood education. It is necessary to give full play to the advantages of art education and \\ cultivate the creativity of young children. At this stage, there are still many problems in children's art education, which \\ is not conducive to the cultivation of children's creative ability. Under the new educational background, it is necessary \\ to innovate children's art education models and cultivate children's artistic literacy.
}

Keywords: nfants; rt education; ountermeasures

Children are a special kind of group. Art education for children should pay attention to the cultivation of children's creativity, give play to the advantages of art education, broaden children's vision, enrich the content of teaching, make children fall in love with art, and appreciate the charm of art. Aiming at the characteristics of children's wide range of hobbies but not focus, teachers should try to expand the content of art course content, not limited to the classroom, can carry out outdoor activities, infiltrate art teaching content in the activities, and stimulate children's creative inspiration.

\section{Status of Early Childhood Art Education}

\subsection{The development of children's art education is not combined with the interests of young children}

At present, in the process of developing art education, some teachers do not design teaching content based on children's hobbies. Some education content is esoteric, and children are not easy to understand, and their learning initiative is not high. In addition, teachers do not teach in layers according to children's interests and learning abilities. The teaching goals are relatively uniform, which is not conducive to cultivating children's creative ability. It also limits children's thinking to some extent.

\subsection{Teachers' subjective consciousness is too respected for children's personality differences}

At present, some teachers occupy the dominant position in the classroom. The entire teaching is mainly based on the completion of the established syllabus. It is not known how many teachers the children have mastered. For example, in the process of painting, blindness is the main focus, which limits children's imagination. In dance teaching, children are always required to copy the teacher's dance movements. Children's learning is passive. They do not enjoy the fun of art courses, which is not conducive to the cultivation of children's overall artistic perception.

\subsection{Did not create opportunities for young children to show themselves}

At this stage, many children's teachers still adopt the traditional teaching mode. Teachers mainly give lectures. Children are in a passive learning position. They learn knowledge mechanically, and the internalization speed is Copyright (C) 2020 Shufang Xiao et al

doi: $10.18282 /$ le.v9i6.1335

This is an open-access article distributed under the terms of the Creative Commons Attribution Non-Commercial License

(http://creativecommons.org/licenses/by-nc/4.0/), which permits unrestricted non-commercial use, distribution, and reproduction in any medium, provided the original work is properly cited. 
relatively slow. Judging from the characteristics of children's physical and mental development, children of this age are more curious and have a certain desire to express. By expressing their emotional feedback on the perception of art, they know the world around them. However, some teachers did not create opportunities for children to show themselves in the process of art education, which deprived children of the right to actively recognize art courses to a certain extent.

\section{Key measures to improve the effectiveness of early childhood art education}

\subsection{Respect children's interests}

In the process of art education content and curriculum arrangement, teachers must fully design children's interests and age characteristics, and in the process of teaching, they must continuously sum up teaching experience and adjust teaching methods. The content chosen must be easy and appropriate, from simple to complex. Let young children have a good transition. For example, in painting teaching, you should start with copying, then imitate painting, and then create your own, gradually improving the creativity of young children. In addition, the teaching of painting should also pay attention to the cultivation of children's aesthetic ability. Teachers can use multimedia to play several sets of photos, let the children analyze the characteristics of these pictures, and talk about which one they like the most, and explain the reason, and gradually cultivate the children's aesthetic ability. To better appreciate works of art. In addition, teachers should implement layered teaching according to the children's actual learning abilities and hobbies. For example, in dance teaching, for small children, they should start with a sense of rhythm. They can play appropriate music to the children to cultivate their sense of rhythm and mobilization. Children's motivation to learn. For young children in the middle class, they should pay attention to movement training. They can disassemble dance movements, correct their movements, and then train continuous movements. For children in large classes, we should pay attention to the combination of movement and music, and guide children to complete a complete set of dance moves.

\subsection{Restore children's subjective status}

Teachers should put children in a dominant position. In the process of art education, they should be able to make it easy. After a certain teaching content is completed, the children's learning results should be tested. After the children have absorbed it, they can proceed to the next content teaching to allow them to internalize Time for knowledge. In the teaching process, thematic education can be carried out to cultivate children's learning interest. For example, in music teaching, the theme of "love" is selected according to the children's interests and hobbies. For example, "In the world, only mothers are good." "," Dedication of love ", etc., respect children's subjective status, and fully mobilize their enthusiasm for learning. Pay attention to the integration of multiple art activities. In painting teaching, teachers can integrate music, play music according to children's interests, assist children to complete painting works, and create a relaxing and pleasant learning environment for children.

\subsection{Create opportunities for young children to show themselves}

In children's art education, teachers need to create opportunities for children to show themselves. Teachers should innovate teaching content, break the traditional teaching mode, and scientifically select teaching content. As depicted in "Colors of Spring", first of all, teachers need to guide children to participate. They can use multimedia or other teaching equipment to create a good learning atmosphere for children and quickly integrate them into the learning environment. Second, lock the teaching theme, but do not limit the answers, so that children can give full play to their imagination and paint the scenes of spring. Finally, increase the frequency of teacher-student interactions to help young children solve problems encountered in the creative process and improve their artistic literacy.

\subsection{Increase the proportion of practical courses}

In art education, teachers should appropriately increase the proportion of practical courses. For example, in music teaching, children's personal performance should be paid attention to, and children's chorus, duet or solo should be organized, and the children's favorite expressions should be selected to display the learning content, so that children can deepen their understanding of theoretical knowledge in the process of practice. 


\section{Concluding remarks}

The art education for young children should be based on their interests and teaching. At the same time, we must also pay attention to the cultivation of children's aesthetic ability, create a good learning environment for children, enable children to quickly integrate into the environment, and stimulate their creativity. In addition, art education cannot be restricted to one form. It is necessary to enrich the teaching content, pay attention to the combination between different projects, exert the best effect of art teaching, and improve children's artistic literacy.

\section{References}

1. Cang Wenling. Discussion on Inspiration Strategies of Art Literacy in Kindergarten Education Stage [J]. Mingshi Online, 2018, 7 (34): 48-49.

2. Zhang Yiping. On the Aesthetic Essence of Children's Art Education Activities [J]. Talents, 2018, 9 (25): 2.

3. Wang Lei, Fang Wenyan. Practice and Research of Folk Art Activities in Preschool Art Education [J]. Educational Observation (Second Half), 2017, 6 (02): 103-105. 